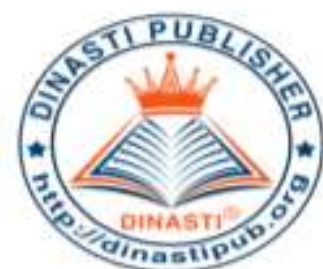

$\leq \triangle$ DIJMS
+6281387654578

$+6281387654578$

https://dinastipub.org/DIJMS

dinasti-info@gmail.com

\title{
THE EFFECT OF LEADERSHIP BEHAVIOUR AND REWARD SYSTEM ON THE EMPLOYEE PERFORMANCE MEDIATED BY ORGANIZATIONAL CITIZENSHIP BEHAVIOUR OF PT DANPAC PHARMA
}

\author{
Ika Lavena ${ }^{1}$, Singmin Johannes Lo ${ }^{2}$ \\ ${ }^{1)}$ Master of Management, Mercu Buana University, Jakarta, Indonesia \\ ${ }^{2)}$ Lecturer of Master of Management, Mercu Buana University, Jakarta, Indonesia
}

\begin{tabular}{|c|c|}
\hline $\begin{array}{l}\text { ARTICLE INFORMATION } \\
\text { Received: } 29 \text { February } 2020 \\
\text { Revised: } 02 \text { March } 2020 \\
\text { Issued: } 07 \text { March } 2020 \\
\text { (filled in by Editor) } \\
\text { Corresponding author: first author } \\
\text { E-mail: } \\
\text { ikalavena12@gmail.com } \\
\text { singmin.johanes@ mercubuana.ac.id } \\
\end{array}$ & $\begin{array}{l}\text { Abstract: The purpose of this research is to } \\
\text { understand and explain the effect of Leadership } \\
\text { Behavior and Reward System on Employee } \\
\text { Performance is mediated by Organizational } \\
\text { Citizenship Behavior for Employees PT Danpac } \\
\text { Pharma. The method used is quantitative approach, } \\
\text { where the population in this study were } 305 \\
\text { employees of PT Danpac Pharma. Engineering } \\
\text { sample selection is done by taking a sample saturated } \\
\text { to permanent employees as much as } 146 \text { respondents. } \\
\text { Questionnaire survey instrument used data collection } \\
\text { techniques and have been submitted to the employees } \\
\text { of PT Danpac Pharma. Data of this study, which } \\
\text { analyzed using structural equation models (SEM) } \\
\text { 3.2.8 SmartPLS software program. This study reveaks } \\
\text { that Leadership Behaviour and Reward System have a } \\
\text { significant positive effect on Employee Performance } \\
\text { mediated by Organizational Citizenship Behaviour } \\
\text { both partially and simultaneously. In addition, the } \\
\text { Leadership Behavior has a positive and significant } \\
\text { effect on Organizational Citizenship Behavior and } \\
\text { Reward System has a positive and significant effect } \\
\text { on Organizational Citizenship Behavior. Leadership } \\
\text { Behavior has a positive and significant effect on } \\
\text { Employee Performance and Reward System has a } \\
\text { positive and significant effect on Employee } \\
\text { Performance. } \\
\text { Keywords: Leadership Behavior, Reward System and } \\
\text { Organizational Citizenship Behavior, Employee } \\
\text { Performance. }\end{array}$ \\
\hline
\end{tabular}




\section{INTRODUCTION}

Human resources is one of the most important things in an effort to achieve the success of an organization. According Arianto (2013) human resources (HR) is one of the most valuable asset owned by an organization, because it is man who is the only resource that can mobilize other resources. Order management activity goes well, the company tried to improve its human resources, because it is a key factor for improving the performance of employees. Therefore, efforts to improve the performance of employees is the most serious challenge for the leader to achieve success depends on the quality of the performance of human resources that exist therein.

Table 1.1. Recapitulation Employee Performance Year 2016 - 2018

\begin{tabular}{|c|c|c|c|c|c|c|c|c|c|c|c|c|c|}
\hline \multirow{3}{*}{ No } & \multirow{3}{*}{ Division } & \multicolumn{12}{|c|}{ Tahun } \\
\hline & & \multicolumn{4}{|c|}{2016} & \multicolumn{4}{|c|}{2017} & \multicolumn{4}{|c|}{2018} \\
\hline & & A & $\mathrm{B}$ & $\mathrm{C}$ & D & A & $\mathrm{B}$ & C & D & A & $\mathrm{B}$ & C & D \\
\hline 1 & General Affairs & 20.68 & 50.13 & 23.14 & 6.05 & 16.82 & 47.9 & 27.56 & 7.72 & 22.72 & 50.26 & 24.35 & 2.67 \\
\hline 2 & Finance \& Accounting & 18.47 & 48.22 & 27.2 & 5.01 & 17.32 & 45.63 & 31.12 & 5.93 & 19.57 & 51.65 & 25.67 & 3.11 \\
\hline 3 & Marketing \& Sales & 20.32 & 52.36 & 25.32 & 2 & 17.84 & 42.19 & 35.83 & 4.14 & 24.68 & 54.12 & 19.39 & 1.81 \\
\hline 4 & Modern Market & 21.05 & 52.4 & 23.45 & 3 & 15.61 & 48.72 & 27.15 & 8.52 & 23.41 & 48.92 & 24.72 & 2.95 \\
\hline 5 & Human Resources & 22.79 & 52.55 & 24.51 & 0.15 & 18.43 & 48.91 & 29.69 & 2.97 & 25.83 & 48.96 & 24.92 & 0.29 \\
\hline 6 & Product Management & 23.05 & 53.61 & 23.62 & 0.52 & 20.55 & 48.97 & 25.92 & 4.56 & 23.5 & 49.78 & 24.17 & 2.55 \\
\hline 7 & Bussiness Development & 21.13 & 51.77 & 25.77 & 2.33 & 19.67 & 49.02 & 27.46 & 3.85 & 23.51 & 50.82 & 23.05 & 2.62 \\
\hline 8 & Logistic & 21.22 & 55.89 & 23.89 & 0.2 & 22.7 & 49.07 & 24.02 & 4.21 & 24.31 & 51.11 & 23.25 & 0.83 \\
\hline 9 & IT & 18.25 & 53.93 & 25.92 & 3.1 & 22.71 & 50.02 & 24.05 & 3.22 & 23.58 & 49.02 & 25.1 & 2.3 \\
\hline 10 & Marketing Support \& Planning & 16.28 & 54.101 & 27.101 & 2.41 & 22.73 & 50.07 & 24.09 & 3.11 & 23.62 & 50.01 & 25.12 & 1.25 \\
\hline 11 & Produksi & 23.3 & 53.117 & 22.119 & 0.64 & 19.62 & 50.1 & 27.65 & 2.63 & 25.18 & 53.05 & 20.9 & 0.87 \\
\hline & Rata-Rata & 20.59 & 52.55 & 24.73 & 2.31 & 19.45 & 48.24 & 27.69 & 4.62 & 23.63 & 50.70 & 23.69 & 1.93 \\
\hline
\end{tabular}

Judging from the previous table, this shows that the performance of employees at PT Danpac Pharma fluctuating. The excellent performance is the optimal performance, the performance of the corresponding enterprise standards and promote the goals of the company. If the employee is not the optimal performance will certainly affect the quality of the company.

Table 1.2. Results of Preliminary Study On Employee Performance

\begin{tabular}{llccc}
\hline \multirow{2}{*}{ No. } & \multicolumn{1}{c}{ Indicator } & \multicolumn{2}{c}{ Selection } & \multirow{2}{*}{ Nes } \\
\cline { 3 - 4 } & \multicolumn{1}{c}{$\begin{array}{l}\text { I have high enthusiasm in carrying } \\
\text { out the work. }\end{array}$} & 8 & 22 & 30 \\
& My coworkers can work just as well. & 12 & $73 \%$ & $100 \%$ \\
\hline 2. & $40 \%$ & $60 \%$ & 30 \\
& & 10 & 20 & 30 \\
\hline 3. & $\begin{array}{l}\text { I feel my job is now according to my } \\
\text { ability. }\end{array}$ & $33 \%$ & $67 \%$ & $100 \%$ \\
\hline
\end{tabular}

Source: Preliminary Results of Pre-Research (2019)

The author interviewed the directors of PT Danpac Pharma is the operational part that has been working for 15 years, it was revealed that the performance of employees in this company down due to lack of optimal thus maximizing the performance of existing jobdesc 
not exceed the company's expectations. Employee performance is also effectd by the behavior of the leader of one of them in a way that is good and smooth communication for employees, reward performance that has been proven by completing jobdesc well and significant progress in its performance. As well as voluntary employees are still lacking ideas and creativity to look for opportunities to promote the company although outside of jobdesc predetermined.

From previous studies proposed by Juanti (2017) that the results of research leadership and organizational culture partially no effect on the performance of employees in hospitals kudungga, while the motivational effect on the performance of employees in hospitals kudungga Kutai Timur.Penelitian Posuma

(2013) states that in partial leadership has no significant effect on employee performance. Research Munparidi (2012) also states that the variable is not significant leadership on employee performance. While research Partini and Hartono (2013), states that leadership and significant positive effect on employee performance. Research Mantauv (2013) also assert leadership positive significant effect on employee performance.

Seeing these conditions, of course, the author tries to carry out a preliminary study to look at the factors that effect the performance of employees. This preliminary study itself is done on the employees of PT Danpac Pharma granted to 30 employees as respondents. Their assessment of the 10 independent variables that the authors offer to the question "In your opinion what factors most affect the performance of employees?" (The answer is recommended at least three options). The following are the results of preliminary studies that have been done are presented in Table 1.3. the following :

Table 1.3. Results of Preliminary Studies Research

\begin{tabular}{llcc}
\hline \multirow{2}{*}{ No. } & \multicolumn{2}{c}{ Variables } & \multicolumn{2}{c}{ Selection } \\
\cline { 3 - 4 } & & Yes & No \\
\hline 1. & Job satisfaction & 12 & 18 \\
\hline 2. & Organizational commitment & 3 & 21 \\
\hline 3. & turnover & 22 & 27 \\
\hline 4. & Leadership Behaviour & 7 & 23 \\
\hline 5. & communication Organization & 9 & 21 \\
\hline 6. & Work motivation & 17 & 13 \\
\hline 7. & Reward system & 11 & 19 \\
\hline 8. & Culture Organization & 5 & 25 \\
\hline 9. & Job competence & 14 & 16 \\
\hline 10. & Citizenship Organizatioal bahaviour & & \\
Source: & The results of the initial survey research (2019). &
\end{tabular}

In ideal conditions, the employee should have a role OCB to show voluntary behavior to want to do the task or other work outside their own responsibilities and obligations for the 
achievement of organizational goals. Unfortunately, based on the results of preliminary observations on the research, organizational citizenship behavior displayed on the PT Danpac Pharma has not been accurate, the researchers conducted a pre-survey as presented in Table 1.4. as follows :

Table 1.4. Results of Preliminary Study Regarding Organizational citizenship behavior

\begin{tabular}{llccc}
\hline \multirow{2}{*}{ No. } & \multicolumn{1}{c}{ Indicator } & \multicolumn{2}{c}{ Selection } & \multirow{2}{*}{ N } \\
\cline { 3 - 4 } & \multicolumn{1}{c}{ Yes } & No & \\
\hline 1. & $\begin{array}{l}\text { I am willing to work overtime to help co- } \\
\text { workers get the job done without incurring } \\
\text { overtime wages. }\end{array}$ & 5 & 25 & 30 \\
& & $83 \%$ & $100 \%$ \\
\hline 2. & $\begin{array}{l}\text { I never complained about the new tasks } \\
\text { given and corporate policies. }\end{array}$ & 12 & 18 & 30 \\
\hline 3. & $\begin{array}{l}\text { I am willing to attend an agenda, although } \\
\text { not required. }\end{array}$ & 8 & $60 \%$ & $100 \%$ \\
\hline
\end{tabular}

Source: Preliminary Results of Pre-Research (2019)

The author interviewed the leaders of PT Danpac Pharma citizeship related to organizational behavior where few employees who instilled helping co-workers outside their job responsibilities. Robbins and Judge put forward facts showing that the organization has employees who have the organizational citizenship behavior (OCB) is good then it will have a better performance than other organizations (Ticoalu, 2013). There are several other factors that affect the incidence of organizational citizenship behavior (OCB) such as, leadership, organizational culture, organizational commitment and others (Wirawan, 2013).

From previous studies proposed by Astrining (2016) that the results of the study there was no significant effect of organizational culture on employee performance with organizational citizenship behavior as an intervening variable. OCB not necessarily mediate between the effect of organizational culture on employee performance. The results are consistent with research conducted by (Chairul, 2014) that the Cultural Organization and no significant negative effect on the performance of employees through the OCB. While research Agnida and Farida (2015).

Table 1.5. Results of Preliminary Study On Leadership Behavior

\begin{tabular}{llcccc}
\hline \multirow{2}{*}{ No. } & \multicolumn{2}{c}{ Indicator } & \multicolumn{2}{c}{ Selection } & \multirow{2}{*}{$\mathrm{N}$} \\
\cline { 3 - 4 } 1. & $\begin{array}{l}\text { My boss was instrumental in } \\
\text { making the decision. }\end{array}$ & 7 & No & \\
\hline 2. & $\begin{array}{l}\text { My boss always gives specific } \\
\text { guidance on how to complete the } \\
\text { task. }\end{array}$ & $\begin{array}{c}40 \% \\
72\end{array}$ & $60 \%$ & $100 \%$ \\
\hline
\end{tabular}




\begin{tabular}{lllccc}
\hline 3. & My boss asked for and use & 9 & 21 & 30 \\
& suggestions from subordinates. & & $30 \%$ & $70 \%$ & $100 \%$ \\
\hline
\end{tabular}

Source: Preliminary Results of Pre-Research (2019)

The author interviewed the leaders of PT Danpac Pharma explaining that behavior here open minded leaders for major directors often come out much work done outside the office then entrust the leadership of top management kesetiap to report every job in the division. But the leadership just ask for advice from the division manager has not reached to the level of staff but not necessarily the advice of the staff was not good for the company.

From previous studies proposed by (Black, 2018) that the results of the study had no direct effect leadership behavior and confidence in the organization's performance through human research relations.Sementara Zaid (2017), states that that leadership behavior has a significant relationship with employee performance kua subdistrict Sekabupaten Tapin.

Table 1.6. Results of Preliminary Study About Reward System

\begin{tabular}{|c|c|c|c|c|}
\hline \multirow{2}{*}{ No. } & \multirow{2}{*}{ Indicator } & \multicolumn{2}{|c|}{ Selection } & \multirow{2}{*}{$\mathrm{N}$} \\
\hline & & Yes & No & \\
\hline 1. & $\begin{array}{l}\text { The salary I receive is in conformity } \\
\text { with the performance that has been } \\
\text { done. }\end{array}$ & $\begin{array}{c}4 \\
13 \%\end{array}$ & $\begin{array}{c}26 \\
87 \%\end{array}$ & $\begin{array}{c}30 \\
100 \%\end{array}$ \\
\hline 2. & $\begin{array}{l}\text { Benefits provided to improve my } \\
\text { performance. }\end{array}$ & $\begin{array}{c}6 \\
20 \% \\
\end{array}$ & $\begin{array}{c}24 \\
80 \%\end{array}$ & $\begin{array}{c}30 \\
100 \%\end{array}$ \\
\hline 3. & $\begin{array}{l}\text { Rewards given are able to provide } \\
\text { motivation to work harder. }\end{array}$ & $\begin{array}{c}10 \\
33 \%\end{array}$ & $\begin{array}{c}20 \\
67 \%\end{array}$ & $\begin{array}{c}30 \\
100 \%\end{array}$ \\
\hline
\end{tabular}

Source: Preliminary Results of Pre-Research (2019)

The author also interviewed leaders of PT Danpac Pharma on the reward system within the company where the chief has not been able to see the full potential in the work so that the employee's performance optimal. Can be calculated a few can achieve grade A, the leadership wants the employees are increasingly being awarded on the good action is done, the greater the employee will improve performance.

From previous studies proposed by Sri, et al (2018) that the results reward negative effect on employee performance while punishment positive effect on the performance of karyawan.Sedangkan ardiansyah (2016) states that that reward positive and significant effect on the performance of employees.

Data from the pre-study, it can be indicated that employee performance is closely related to several factors, such as: Leadership Behavior, Reward System and Organizational Citizenship Behavior. Based on the above information, the need for researchers to examine the theme, "The Effect of Leadership Behavior and Reward System on Employee 
Performance Mediated by Organizational Citizenship Behavior (OCB). (Case Study: PT Danpac Pharma)".

\section{LITERATURE REVIEW}

\section{A. Leadership Behavior}

Robbins (2017) defines the behavior of the leadership as the ability to effect a group of members to work achieve the goals and objectives set. Leadership behavior generally means that certain acts which a leader is involved in the process of directing and coordinating the work of the members of the group. Wahab (2011) is the leadership behavior style of leadership to implement the functions of leadership, which has a very big effect and is very decisive in effecting the organization to achieve its objectives. According Yukl (2017) distinguishes leadership behaviors into three kinds: Task Oriented Behavior, Relationship Oriented Oriented Behavior and Behavior Changed.

\section{B. Reward System}

Moorhead and Griffin (2013) states that the award system (reward system) consists of all components of the organization, including people, processes, rules and procedures, and decision-making activities, is involved in allocating compensation and benefits to employees in return for their contributions on the organization. Dimensions used by Karami (2013) with dimensions rewards system as follows: Financial and Non-Financial Rewards Reward.

\section{Organizational Citizenship Behavior}

According to the Organ (2006) in Budihardjo (2016) OCB is a voluntary behavior of an individual (in this case the employee) that are not directly related to the system pengimbalan but contribute to the organization's effectiveness. In other words, OCB is the behavior of an employee is not because of the demands of his job, but more based on kesukarelaannya. According to internal organs in Tambe and Shanker (2014) there are five dimensions that have contributed in Organizational Citizenship Behavior (OCB), which is conscientiousness, alturism, civic virtue, Sportsmanship, and courtesy.

D. Employee Performance

According to Robbins (2017), employee performance is the result of the quality and quantity of work accomplished by an employee in performing its functions in accordance with the responsibilities given to him. -Indikator indicators of employee performance by Bernadine in Sulastri (2018) are as follows: Quality, Quantity, timeliness, effectiveness, Independence and Initiative. 


\section{E. Conceptual Framework}

Sihombing (2018) revealed that there is significant from serving leadership, appreciation and performance of employees through the organization of citizen behavior. Kartikaningdyah \& Kameliza (2017) the effect of transformational leadership, job satisfaction affects the OCB, but procedural justice had no effect on OCB. OCB mediate transformational leadership on employee performance, OCB also mediate job satisfaction on employee performance, but does not mediate OCB procedural fairness. Michelle and Nainggolan (2018) research shows that the motivation is able to mediate punishment to employee performance but does not mediate reward motivation on employee performance.

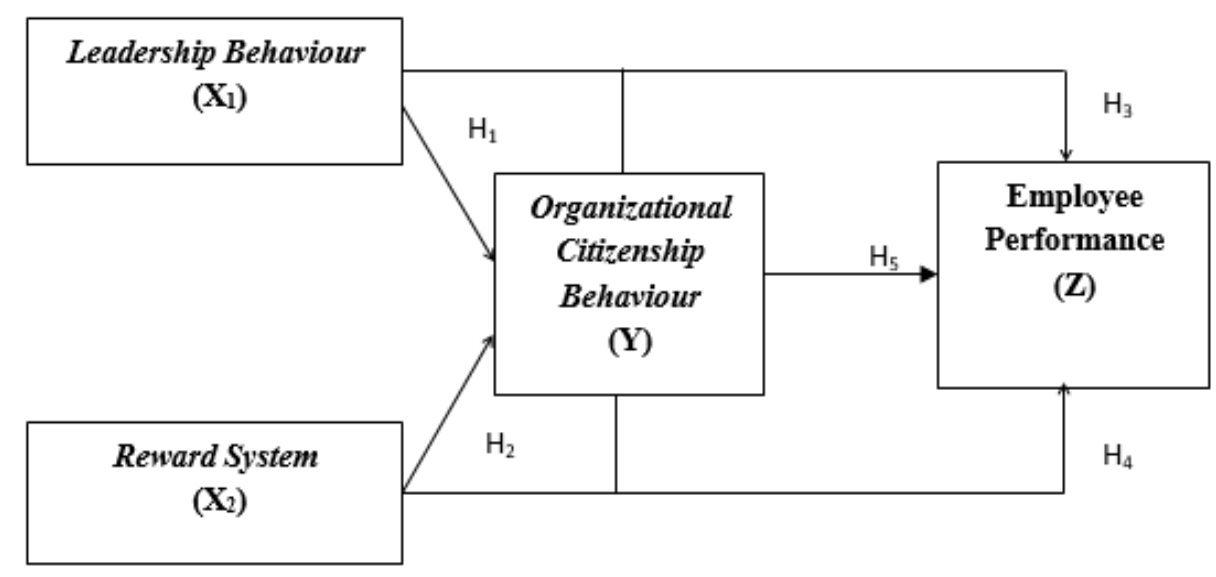

Figure 1: - Theoretical Framework

Source: Theoretical Review

\section{RESEARCH METHODS}

This type of research is quantitative research that uses primary data in the form of a survey in order to complete, relevant and comprehensive data. In addition to the primary data in the form of surveys, researchers used secondary data in the form of an annual assessment scores within three (3) years from PT Danpac Pharma. This study was designed to understand, explain and analyze the relationship between the independent variables on the dependent variables. Solving variables are measured by dimensions and indicators. The number of items is provided in table 1 independent variables (exogenous) was measured with a Likert scale Leadership Behavior (X1) and Reward System (X2), while the dependent variable (endogenous) is Employee Performance (Y) and Organizational Citizenship Behavior (OCB) mediation variable $(\mathrm{Z})$. 
Table 3.1. Variable size

\begin{tabular}{|c|c|c|}
\hline 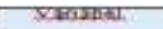 & Dत्यक्यार & मramar \\
\hline \multirow{11}{*}{ 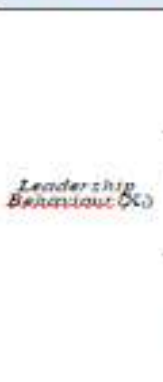 } & \multirow{4}{*}{$\begin{array}{l}\text { That Orieuted } \\
\text { selimiloig (TOB) }\end{array}$} & 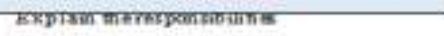 \\
\hline & & 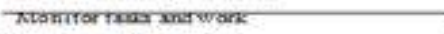 \\
\hline & & 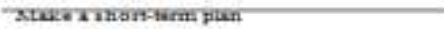 \\
\hline & & 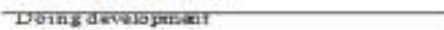 \\
\hline & \multirow{4}{*}{ 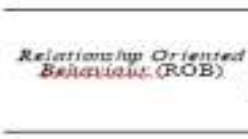 } & एपशpणना \\
\hline & & Comrumrsonा \\
\hline & & oivomisus \\
\hline & & 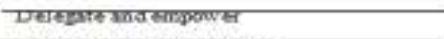 \\
\hline & \multirow{3}{*}{ 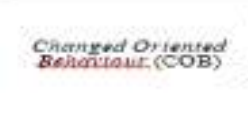 } & 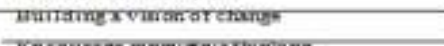 \\
\hline & & 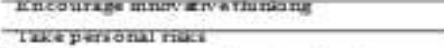 \\
\hline & & 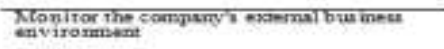 \\
\hline \multirow{2}{*}{ Rewarged $: 30=m$} & 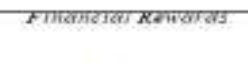 & 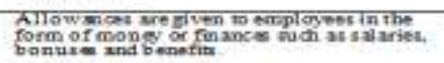 \\
\hline & 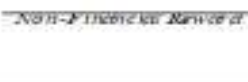 & 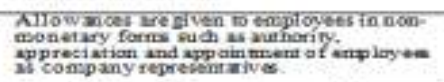 \\
\hline \multirow{10}{*}{ 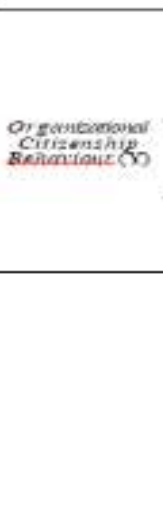 } & \multirow[b]{2}{*}{ ditrutsm } & 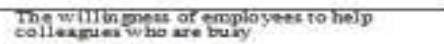 \\
\hline & & 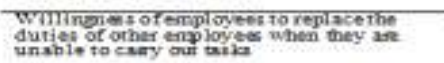 \\
\hline & \multirow{2}{*}{ Crote virate } & 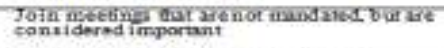 \\
\hline & & 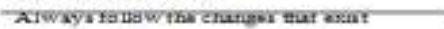 \\
\hline & \multirow{2}{*}{ Canseremransnest: } & 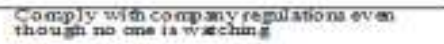 \\
\hline & & 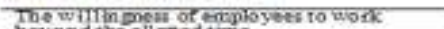 \\
\hline & \multirow{2}{*}{ Courtesy } & $\begin{array}{l}\text { Awareness of employees to alw ays maintain } \\
\text { relations hips in order to avo id inteppersonal } \\
\text { problems with colleggues and supenors }\end{array}$ \\
\hline & & $\begin{array}{l}\text { Employee arvareness not to create problems } \\
\text { with other enployees }\end{array}$ \\
\hline & & Do not hile to complayn at work: \\
\hline & Sportsmanship & $\begin{array}{l}\text { Don't spend a lot of time internupting } \\
\text { (pitting) about problems that arenot } \\
\text { inportant or trivial }\end{array}$ \\
\hline \multirow{7}{*}{$\begin{array}{l}\text { Employee } \\
\text { Performance } \\
\text { (Z) }\end{array}$} & \multirow[b]{2}{*}{ Kualitas. } & Means of work that can be used \\
\hline & & $\begin{array}{l}\text { Work load is completed and inline with } \\
\text { expectations }\end{array}$ \\
\hline & Kuantitas & Quality of completed taals \\
\hline & Retepaatan waktu & T11meliness m completmg tasks \\
\hline & Kerandician & Independence in completmg tasks \\
\hline & Inisiatif & Inftaltrve in inprovmg group perto andance \\
\hline & Efelctivitas & Makce use of thife and works tools \\
\hline
\end{tabular}

Population and Sampel

According Sugiyono (2017), the population consists of objects and subjects who have the qualities and characteristics that are determined by certain researchers to learn and then drawn conclusions. In this study population of 146 permanent employees of PT Danpac Pharma.

These studies use data analysis techniques SmartPLS 3.2.8 and executed by the computer. Least Square (PLS) is a structural equation modeling (SEM) analysis using a partial variants simultaneously to test the measurement model and the structural model. The model is used to run the test validity and reliability, while the structural model used to run tests of causality (Hypothesis testing using predictive models).

Through PLS, it is assumed that all variants can be used to explain the data analysis. Techniques in the study were divided into two (2), such as: 
- Descriptive statistical analysis is an empirical analysis that describes information obtained from a figure or explain certain cases (Who / what, when, where, how and how much) and collected in the study.

- inferential statistical analysis is a statistical technique that will be used to analyze the sample data and results will be used for population (Sugiyono, 2017). Together with the hypothesis, that the inferential statistical data analysis in this study will use SmartPLS (Partial Least Square) software to model the external, inner and measurement model hypotheses.

\section{FINDINGS AND DISCUSSION}

Finding

The results of analysis of data obtained from this study compiled descriptive of each variable by distributing questionnaires to 146 respondents employees of PT Danpac Pharma. Based on the results, there were 75 male employees with a percentage of $51 \%$ and 71 employees with a percentage of $49 \%$ women. In terms of age, there were 71 employees in the age of 21-30 years with a percentage of 49\%, 48 employees in the age of 31-40 years with a percentage of $33 \%, 20$ employees in the age of 41-50 years with a percentage of 14\%, 5 employees at the age of 51-60 year with a percentage of 3\% and 2 employees in more than 60 years of age with a percentage of $1 \%$. Based on the latest educational background, there are 77 high school employees with a percentage of $53 \%$, there are 6 Diploma Employees with a percentage of 4\%, 53 Graduate Employees with a percentage of 36\%, 10 percentage of employees Graduate with 7\%. Based on the length of employment,

Descriptive statistical analysis is used to understand the tendency to answer the questionnaire or how far the response of respondents based on category selection linkert scale use of a scale of 1 (Strongly disagree) to 5 (Strongly agree) for each variable statement. Based on data collected, which are then tabulated to determine the distribution of responses of each indicator for each of the variables and the results showed the following :

- Variable leadership behavior has an average of 4.36, which means that the interval is included in the category Agree with the statement given item, so that it can be concluded that the leadership behavior experienced by employees affect job responsibilities. 
- Variable reward system has an average of 4.46 , which means that the interval is included in the category of the item Agreed statements. From the information above, we can conclude that the reward system effects on employee benefits.

- Variable employee has an average performance of 4.31, which means that the interval is included in the category of the item given Agreed statement, so that it can be concluded that employees with good performance to complete the task on time.

- OCB variables had an average of 4.25 , which means that the interval is included in the category of the item given Agreed statement, so that it can be concluded thatemployees are happy to help colleagues in need.

Expenditure Model Evaluation Evaluation is the measurement model evaluation model inter construct an indicator that consists of two models: (1) convergent validity, (2) discriminant validity. Convergent validity can be evaluated by three stages: (1) the validity indicator, (2) reliability construct and (3) the avarage variance extracted (AVE). While discriminant validity can be in two stages: (1) see the value of cross loading and (2) comparing the correlation between the constructs with roots AVE.

Test Validity Convergent Validity 1. Indicator convergent validity value is the value of the latent variable loading factor on the indicator. According Ghozali and Latent (2015), an indicator of the individual is considered reliable if the value of correlation $>0.7$, but in the research stage of development of the scale, loading 0.50 to 0.60 is acceptable. To conduct the next test phase to test reliability, invalid data should be removed and done PLS Algorithm and bootstrapping reconfigured so that the value indicator on the loading factor valid. Here is the output PLS structure after the removal of invalid indicator.

Figure 2: Model Value Inter Construct

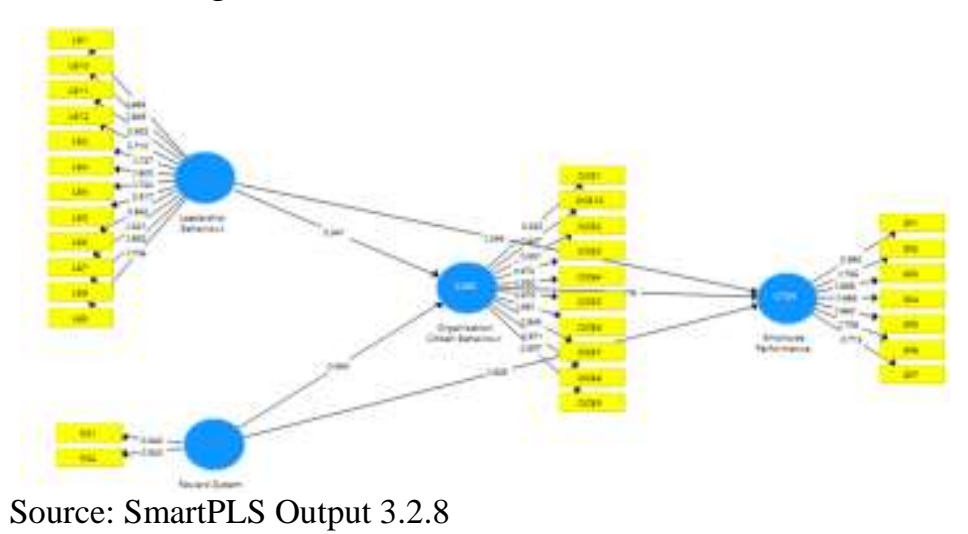

In figure 2 all the indicator value above 0.7 making it eligible for the study. These results can also be seen from outer loading the table below: 
Table 4.1. Loading Value Factor

\begin{tabular}{|c|c|c|c|c|}
\hline variables & Indicator & $\begin{array}{c}\text { Loading } \\
\text { Outer Value }\end{array}$ & requirement & Information \\
\hline \multirow{12}{*}{$\begin{array}{l}\text { Leadership } \\
\text { Behavior (X1) }\end{array}$} & LB01 & 0.899 & $>0.7$ & valid \\
\hline & LB02 & 0.737 & $>0.7$ & valid \\
\hline & LB03 & 0.800 & $>0.7$ & valid \\
\hline & LB04 & 0.722 & $>0.7$ & valid \\
\hline & LB05 & 0.917 & $>0.7$ & valid \\
\hline & LB06 & 0.862 & $>0.7$ & valid \\
\hline & LB07 & 0.921 & $>0.7$ & valid \\
\hline & LB08 & 0.892 & $>0.7$ & valid \\
\hline & LB09 & 0.706 & $>0.7$ & valid \\
\hline & LB10 & 0.846 & $>0.7$ & valid \\
\hline & LB11 & 0.855 & $>0.7$ & valid \\
\hline & LB12 & 0.710 & $>0.7$ & valid \\
\hline \multirow{2}{*}{$\begin{array}{c}\text { Reward System } \\
\text { (X2) }\end{array}$} & RS01 & 0.943 & $>0.7$ & valid \\
\hline & RS02 & 0.924 & $>0.7$ & valid \\
\hline \multirow{10}{*}{ OCB (Z) } & OCB01 & 0.935 & $>0.7$ & valid \\
\hline & OCB02 & 0.951 & $>0.7$ & valid \\
\hline & OCB03 & 0.973 & $>0.7$ & valid \\
\hline & OCB04 & 0.950 & $>0.7$ & valid \\
\hline & OCB05 & 0.972 & $>0.7$ & valid \\
\hline & OCB06 & 0.961 & $>0.7$ & valid \\
\hline & OCB07 & 0.843 & $>0.7$ & valid \\
\hline & OCB08 & 0.971 & $>0.7$ & valid \\
\hline & OCB09 & 0.957 & $>0.7$ & valid \\
\hline & OCB10 & 0.847 & $>0.7$ & valid \\
\hline \multirow{7}{*}{$\begin{array}{c}\text { Employee } \\
\text { Performance }(\mathrm{Y})\end{array}$} & EP01 & 0.882 & $>0.7$ & valid \\
\hline & EP02 & 0.799 & $>0.7$ & valid \\
\hline & EP03 & 0.898 & $>0.7$ & valid \\
\hline & EP04 & 0.883 & $>0.7$ & valid \\
\hline & EP05 & 0.860 & $>0.7$ & valid \\
\hline & EP06 & 0.758 & $>0.7$ & valid \\
\hline & EP07 & 0.715 & $>0.7$ & valid \\
\hline
\end{tabular}

Source: Results of analysis using SmartPLS 3.2.8 (2019)

\section{A. Construct Test Reliability}

Reliability tests performed to prove the accuracy, consistency and accuracy of instruments to measure the construct. To determine the reliability of a construct can be calculated by using Cronbach's Alpha (CA) and Composite Reliability (CR). The following table reliability test of the research:

- Composite Reliability Rule of thumb commonly used to assess the reliability of composite Reliability construct value must be greater than 0.7 for studies that are confirmatory and the value of $0.6-0.7$ is still acceptable for research is explanatory. 
Table 4.3. Composite Reability

\begin{tabular}{lccl}
\hline \multicolumn{1}{c}{ Variables } & $\begin{array}{c}\text { Composite } \\
\text { Reliabity }\end{array}$ & Requirement & Information \\
\hline Leadership Behavior & 0.962 & $>0.7$ & reliable \\
Reward System & 0.931 & $>0.7$ & reliable \\
Organizational Citizenship & 0.988 & $>0.7$ & reliable \\
Behavior & & & reliable \\
Employee Performance & 0.935 & $>0.7$ & \\
\hline
\end{tabular}

Source: Results of analysis using SmartPLS 3.2.8 (2019)

Table 4.3. a composite value of the reliability of the model study showed that each variable has had a composite value reliability above 0.7 with the lowest value for 0.931 of variable Reward System (X2) and the highest value for 0.988 of variable Organizational Citizenship Behavior (Z). From these results it can be concluded that research model has met the composite value of reliability.

- Cronbach's Alpha subsequent reliability testing is testing the value of Cronbach's alpha, with the expected value is 0.6 for all constructs.

Table 4.4. Cronbach's alpha

\begin{tabular}{lccc}
\hline \multicolumn{1}{c}{ Variables } & $\begin{array}{c}\text { Cronbach's } \\
\text { Alpha }\end{array}$ & Requirement & Information \\
\hline Leadership Behavior & 0.957 & $>0.6$ & reliable \\
Reward System & 0.853 & $>0.6$ & reliable \\
Organizational Citizenship & 0.984 & $>0.6$ & reliable \\
Behavior & & & reliable \\
Employee Performance & 0.924 & $>0.6$ & \\
\hline
\end{tabular}

Source: Results of analysis using SmartPLS 3.2.7 (2019)

Table 4.4. Cronbach's alpha values of the model study showed that each variable has had a Cronbach's alpha values above 0.6 with the lowest score of 0.853 darivariabel Reward System (X2) and nilaitertinggisebesar 0.984 of variable Organizational Citizenship Behavior (Z). From these results it can be concluded that research model has met the value of Cronbach's alpha. From the model above, it can be concluded that the model has met the criteria Composite Reliability and Cronbach's Alpha so that our model has met the criteria of reliability and a measure that is trustworthy and reliable.

- AVE (Average Variance Extracted) The next method is to test the validity of the data with the Average Variance Extracted (AVE). AVE value if the variable is said to be > 0.5. The following table shows the value AVE of Leadership Behaviour (X1), Reward System (X2), Organizational Citizenship Behaviour (Z) and Employee Performance (Y). 
Table 4.5. The Mean Value Of Average Variance Extracted (AVE) For each variable

\begin{tabular}{lc}
\hline \multicolumn{1}{c}{ Variables } & AVE Value \\
\hline Leadership Organization & 0.682 \\
Reward System & 0.871 \\
OCB & 0.878 \\
Employee Performance & 0.689
\end{tabular}

Source: Results of analysis using SmartPLS 3.2.8 (2019)

The above table shows that all variables have values> 0.50 from AVE.

B. Discriminant Validity

Discriminant validity test can through two stages: (1) see the value of cross loading and (2) comparing the correlation between the constructs with roots AVE.

- Cross Loading Cross loading is another measure of discriminant validity. It is expected that each block of the indicator has a value of loading is higher for each variable latency measured in comparison with indicators for variable latent other value of a correlation indicator variable has a value that is higher than the correlation indicator the indicator by another variable the said variable has discriminant validity were high.

Table 4.6. Loading Cross value of each variable and construct the research model

\begin{tabular}{|c|c|c|c|c|c|c|c|c|}
\hline \multirow{3}{*}{ variatad } & \multirow{3}{*}{ lastikasese } & \multicolumn{7}{|c|}{ Conrelation } \\
\hline & & \multicolumn{7}{|c|}{ 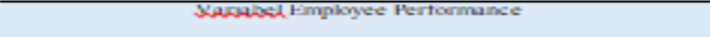 } \\
\hline & & EPI & EPI & $E P_{3}^{3}$ & EP4 & EPS & EPG & EPr \\
\hline \multirow{12}{*}{ 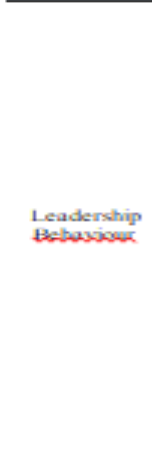 } & LBI & $0.713^{2-0}$ & $0.5 \times 3 \%$ & $0.811 \%$ & $0.700=$ & $0.634^{\circ}$ & $0.550^{\circ}$ & 0.502 \\
\hline & LAB2 & 0.350 & 0.355 & 0.450 & 0.431 & 0.371 & 0.292 & 0.305 \\
\hline & LB3 & 0.445 & $02 \times 4^{4}$ & $0.539^{\circ}$ & $0.534^{\prime \prime}$ & $0.394^{\circ}$ & $0.354^{\circ}$ & 0.374 \\
\hline & $\angle B 34$ & $0.335^{\prime \prime}$ & $0.154^{*}$ & $0.4 \times 1^{* 1}$ & 0.399 & $0.232^{\prime \prime}$ & $0.304^{\prime}$ & $0.26 x^{\prime \prime}$ \\
\hline & LBS & 0.994 & 0.006 & 0.531 & 0.652 & 0.575 & 0.436 & 0.406 \\
\hline & LBS & $0.44^{\circ}$ & $0.492^{\prime \prime}$ & $0.623^{\circ 1}$ & $0 \leq \times 3^{\prime \prime}$ & $0 . \cos ^{\circ}$ & $0.384^{\circ}$ & $0.422^{\prime \prime}$ \\
\hline & LBS & ara4 & $0.595^{\circ}$ & $0.735^{\circ}$ & $0.651^{\circ}$ & 0.625 & $0.462^{2}$ & $0.473^{3+1}$ \\
\hline & LBS & $0.742^{\prime 2}$ & $0.633^{\circ}$ & $0.799^{\circ}$ & $0.654^{\circ}$ & $0.624^{\circ}$ & $0 \times 44^{\prime}$ & 0.499 \\
\hline & LAS & 0.331 & 0.340 & 0.432 & 0.425 & 0.351 & 0350 & 0.362 \\
\hline & LBIO & $0.531^{7}$ & $0.427^{\circ}$ & $0.646^{\circ}$ & $0.4 \times 5$ & $0.510^{\circ}$ & $0.441^{7}$ & $0381^{2}$ \\
\hline & LBII & $0.591^{\circ}$ & $0.451^{\prime \prime}$ & $0.674^{\prime \prime}$ & $0.41^{\prime \prime}$ & $0.491^{*}$ & $0.438^{\prime}$ & $0.444^{\circ}$ \\
\hline & LBIZ & 0.418 & 0.412 & 0.491 & 0.406 & 0.410 & 0233 & 0.292 \\
\hline \multirow{2}{*}{ Reward Systen } & RSI & a.tss & $a \leq 65^{\circ}$ & 0.815 & $0.502^{2}$ & $0.595^{\circ}$ & 0.516 & $0.551^{\prime}$ \\
\hline & RS2 & 0.663 & 0.451 & $0.651^{-}$ & $0.640^{\circ}$ & $0.613^{-}$ & 0.595 & 0.65 \\
\hline \multirow{10}{*}{$\alpha C B$} & OCBI & $0.520^{\circ}$ & 0.395 & 0.659 & $0.5 \times 5$ & 0.46 & 0.453 & $0.45 z^{-}$ \\
\hline & $6 K \mathrm{BS}^{2}$ & $0 \leq 42$ & 0.353 & $0.6 \times 4$ & 0.612 & $a s e x$ & 0.475 & 0.471 \\
\hline & $\mathrm{OCB}^{3}$ & 0.644 & 0,524 & $2 . \pi 03$ & $0.652^{-}$ & 0.005 & 0.456 & $0.501^{-}$ \\
\hline & OCBA & 0.47 & $0.400^{\circ}$ & 20.659 & 0.617 & $0.6 x^{-1}$ & $0.474^{4}$ & $0.471^{-}$ \\
\hline & CK.BS & 0.046 & 0,23 & 0.104 & 0.653 & 0.006 & $0.4 \times 5$ & 0.500 \\
\hline & OCAB & 0.604 & $0.492^{-}$ & $0.6055^{\circ}$ & 0.609 & a.s? & 0.459 & $0.539^{\prime}$ \\
\hline & $\mathrm{OCBS}$ & 0.424 & $0.415^{-}$ & 0.446 & 0.419 & $0.550^{\circ}$ & 0.438 & $0.473^{-}$ \\
\hline & OCABS & $0.640^{\circ}$ & 0.518 & a.ra3 & 0.647 & $0.601^{-}$ & $0.4 \pi 9$ & 0.496 \\
\hline & 6R. & 0.026 & 0,29 & $0.06 x$ & 0.000 & $0.5 \%$ & $0.44 x$ & 0.300 \\
\hline & OCB1O & $0.416^{\circ}$ & $0.401^{-}$ & $0.443^{-}$ & $0.432^{-}$ & $0.599^{-1}$ & 0.458 & $0.4 \times 7^{\prime}$ \\
\hline
\end{tabular}

Source: Results of analysis using SmartPLS 3.2.8 (2019) 
From Table 4.6. seen that the correlation construct the indicator is greater than the correlation value with konstruklainnya. It can be concluded that all latent constructs showed good discriminant validity because it can predict the indicator on the block they are better than the indicator in the other block.

Evaluation models Structural (mental models) or testing this hypothesis is done in several steps, such as evaluating the coefficient value evaluation Path R2, the measurement of the effect size F2, validate the structural model of the whole by using goodnes of Fit Index (GOF) and also test the relevance of predictive (Q2), Meanwhile SmartPLS 3.2.8.

Leadership variables simultaneously effect behavior, reward system on Organizational Citizenship Behavior can be done by calculating the arithmetic f / f statistic using the formula as below.

a. $\mathrm{R} 2=0.560(\mathrm{OCB})$

$$
\begin{aligned}
& F \text { count }=\frac{\frac{R^{2}}{(k-1)}}{1-R^{2} /(n-k)} \\
& \text { Fcount }=\frac{\frac{0.560}{(4-1)}}{1-(-1,56 n /(145-1)} \\
& F \text { count }=0.187 / 0.0031 \\
& F \text { count }=60.32
\end{aligned}
$$

Leadership variables simultaneously effect behavior, reward system, organizational citizenship behaviour on employee performance can be done by calculating the arithmetic $\mathrm{f} /$ f statistic using the formula as below.

b. $\mathrm{R} 2=0.724(\mathrm{EP})$

$$
\begin{aligned}
& \text { F count }=\frac{\frac{R^{2}}{(k-1)}}{1-R^{2} /(n-k)} \\
& \text { Fcount }=\frac{\frac{0,724}{(1-1)]}}{1-(0,721 /(146-1)} \\
& F \text { count }=0.241 / 0.0019 \\
& F \text { count }=126.84
\end{aligned}
$$

The Results is Significant and simultaneously for hypothesis 5 in this study. The calculated $\mathrm{F}$ value in this study is 60.32 and $126.84 \mathrm{~F}$ table values on $(\mathrm{df} 1=4-1$; df $2=146-4)$ alpha 0.05 is 2.67. This means that $\mathrm{f}$ count $>\mathrm{f}$ Table (2.67), then H5 is accepted. To evaluate the score R2, SmartPLS 3.0 algorithm used in the following versions:

Table 4.8. R-Square Score (R2)

\begin{tabular}{ll}
\hline Konstruk & $\boldsymbol{R}$-Square \\
\hline Organization Citizen Behaviour & 0.560 \\
Employee Performance & 0.724 \\
\hline
\end{tabular}

Source: Results of analysis using SmartPLS 3.2.8 (2019) 
a Rated R-square variable Organizational Citizenship Behavior (Z) is equal to 0.560 it showed that $56 \%$ of the variable Organizational Citizenship Behavior (Z) can be affected by variables Leadeship Behavior (X1), and a variable Reward System (X2) while the remaining $44 \%$ are effectd by other than the studied variables.

b. R-square value of the variable Employee Performance (Y) is equal to 0.724, this shows that $72.4 \%$ variable Employee Performance (Y) can be affected by variables Leadeship Behavior (X1), Reward System (X2), and variable Organizational Citizenship Behavior $(Z)$, while the remaining $27.6 \%$ is effectd by other variables outside studied.

The purpose of doing testing Goodness of Fit Index $(\mathrm{GoF})$ is to validate the performance of the combination of the measurement model (outer model) and structural models (inner model) obtained through the following calculation:

$$
\begin{aligned}
& \mathrm{GoF}=\sqrt{A V E x R^{2}} \\
& \mathrm{GoF}=\sqrt{0,78 \times 0,203} \\
& \mathrm{GoF}=\sqrt{0,15834} \\
& \mathrm{GoF}=0.398
\end{aligned}
$$

Information :

$\mathrm{AVE}=(0.682+0.871+0.878+0.689) / 4=$

$$
3.12 / 4=0.78
$$

$\mathrm{R}$ square $=(0.560 \times 0.724) / 2=0.203$

The calculation result Goodness of Fit Index (GoF) shows the value of 0.398. Based on these results it can be concluded that the combined performance measurement model (outer model) and structural models (inner model) as a whole is good because the value of Goodness of Fit Index (GoF) of more than 0.25 (moderate Scale).

\begin{tabular}{|c|c|c|c|c|c|}
\hline $\begin{array}{l}\text { Hubungan Antar } \\
\text { Konstruk }\end{array}$ & $\begin{array}{c}\text { Original } \\
\text { Sample } \\
(O)\end{array}$ & $\begin{array}{l}\text { Sample } \\
\text { Mean (M) }\end{array}$ & $\begin{array}{c}\text { Standard } \\
\text { Deviation } \\
\text { (STDEV) }\end{array}$ & $\begin{array}{c}\text { T Statistics } \\
(/ O / S T D \\
\text { EVII) }\end{array}$ & P Values \\
\hline$L B \rightarrow E P$ & 0.185 & 0.181 & 0.094 & 1.982 & 0.048 \\
\hline LB $\rightarrow$ OCB & 0.341 & 0.340 & 0.098 & 3.470 & 0.001 \\
\hline $\mathrm{OCB} \rightarrow \mathrm{EP}$ & 0.176 & 0.183 & 0.087 & 2.022 & 0.044 \\
\hline SISTEM $\rightarrow$ EP & 0.559 & 0.558 & 0.084 & 6.673 & 0.000 \\
\hline SISTEM $\rightarrow$ OCB & 0.454 & 0.456 & 0.100 & 4.555 & 0.000 \\
\hline \multicolumn{6}{|c|}{ Tidak Langsung (Indirect) } \\
\hline $\mathrm{LB} \rightarrow \mathrm{OCB} \rightarrow \mathrm{EP}$ & 0.060 & 0.062 & 0.035 & 1.711 & 0.088 \\
\hline $\begin{array}{l}\text { SISTEM } \rightarrow \text { OCB } \rightarrow \\
\text { EP }\end{array}$ & 0.080 & 0.084 & 0.047 & 1.689 & 0.092 \\
\hline
\end{tabular}

Effect of hypothesis testing to determine the leadership behavior and reward system on employee performance Mediated by Organizational Citizenship Behavior (OCB) can be seen in the table below:

Table 4.9. Independent variables effect on the dependent variable

Source: Results of analysis using SmartPLS 3.2.8 (2019)

According to the table above for the structural model with the hypothesis is as follows :

1. Hypothesis 1 - Leadership Behaviour has effect to OCB, the path coefficient is 0.341 and the value $p=0.001(p<0.05)$, which means that $H 1$ is accepted and that there is effect between Leadership Behavior and OCB.

2. Hypothesis 2 - Reward System has effect to OCB, the path coefficient is 0.454 and the value $\mathrm{p}=0.000(\mathrm{p}<0.05)$, which means that $\mathrm{H} 2$ is accepted and that there is a significant effect between the Reward System and OCB. 
3. Hypothesis 3 - Leadership Behaviour has effect to Employee Performance, the path coefficient is 0.185 and $\mathrm{p}$-value $=0.048(\mathrm{p}<0.05)$, which means that the $\mathrm{H} 3$ is received and that there is significant effect between Leadership Behavior and Employee Performance.

4. Hypothesis 4 - Reward System has effect to Employee Performance, the path coefficient is 0.559 and $\mathrm{p}$-value $=0.000(\mathrm{p}<0.05)$, which means that the $\mathrm{H} 4$ is accepted and that there is significant effect between the Reward System and Employee Performance.

C. Correlation Matrix

Table 4.10. The correlation matrix dimensions independent and dependent variable

\begin{tabular}{|c|c|c|c|c|c|c|c|c|}
\hline \multirow[t]{2}{*}{ variables } & \multirow[t]{2}{*}{ Indicator } & \multicolumn{7}{|c|}{ Variable Employee Performance } \\
\hline & & EP1 & EP2 & EP3 & EP4 & EPS & EPG & EP7 \\
\hline \multirow{12}{*}{$\begin{array}{l}\text { Leadership } \\
\text { Behavior }\end{array}$} & LB 1 & $.713 * *$ & $.583 * *$ & $.811^{* * k}$ & $.700^{* * *}$ & $.634^{* m+4}$ & $.550^{*+1}$ & $.502^{m+m}$ \\
\hline & LB2 & $.386^{* * *}$ & $.377^{* *+1}$ & $.486^{* * *}$ & $.431^{\text {Nom }}$ & $.371^{m+4}$ & $.292^{* * *}$ & $.307^{m+2}$ \\
\hline & LB3 & $.448^{* *+}$ & $.254^{* *+1}$ & $.539^{* * *}$ & $.534^{*+*}$ & $.394^{m+4}$ & $.354^{* * *}$ & $.374^{m+2}$ \\
\hline & LB4 & $.335^{* * *}$ & $.154 * *$ & $.481^{n+m}$ & $.399^{11+*}$ & $.232^{m+1}$ & $.304^{* *+1}$ & $.268^{* 1=}$ \\
\hline & LB5 & $.594^{m+m}$ & $.506^{* *+1}$ & $.731^{* *+1}$ & $.652^{\text {we* }}$ & $.575^{m+1}$ & $.436^{*+*}$ & $.406^{n+7}$ \\
\hline & LB6 & $.544^{m+4}$ & $.492^{* *+1}$ & $.623^{* *+1}$ & $.583^{m * *}$ & $.505^{m+1}$ & $.384^{* * *}$ & $.422^{m * 4}$ \\
\hline & LB7 & $.704^{m+m}$ & $.595^{* *+\cdots}$ & $.737^{* *+1}$ & $.651^{* * *}$ & $.628^{m+1}$ & $.462^{* * *}$ & $.473^{\text {"NA }}$ \\
\hline & LB8 & $.742^{* * *}$ & $.633^{* *+1}$ & $.759^{* * *}$ & $.684^{1+* *}$ & $.624^{m+1+1}$ & $.544^{* * *}$ & $.499^{m+*}$ \\
\hline & LB9 & $.331^{\text {whe }}$ & $.340^{+* *+}$ & $.432^{*+*}$ & $.427^{1+* *}$ & $.371^{m+1+1}$ & $.350^{* * *}$ & $.362^{n+4}$ \\
\hline & LB10 & $.531^{n+*}$ & $.427^{*+*}$ & $.646^{*+1+}$ & $.488^{* * *}$ & $.510^{m+1}$ & $.441^{*+*}$ & $.381^{\text {we }}$ \\
\hline & LB11 & $.591^{m+*}$ & $.451^{* *+1}$ & $.674^{* *+1}$ & $.541^{\text {wa* }}$ & $.491^{m+1}$ & $.438^{* * *+1}$ & $.444^{n+*}$ \\
\hline & LB12 & $.418^{* * *}$ & $.412^{* * * 1}$ & $.491^{*+*}$ & $.406^{\prime \prime \prime \prime}$ & $.410^{m+1}$ & $.233^{* * *}$ & $.292^{n+*}$ \\
\hline \multirow[b]{2}{*}{$\begin{array}{l}\text { Reward } \\
\text { System }\end{array}$} & RS1 & .788 & $.565^{\circ}$ & $.818^{\prime \prime}$ & $.802^{\prime \prime}$ & $.595^{\circ}$ & $.516^{\circ}$ & $.551^{\circ}$ \\
\hline & RS2 & $.663^{*}$ & $.481^{* *}$ & $.661^{*}$ & $.640^{\prime \prime}$ & $.613^{* 1}$ & $.595^{\prime \prime}$ & $.565^{* 1}$ \\
\hline \multirow{8}{*}{ OCB } & OCB 1 & .520 & .397 & .659 & .588 & .546 & $.453^{\circ}$ & $.452^{\circ}$ \\
\hline & $\mathrm{OCB} 2$ & .542 & .393 & .684 & .612 & .568 & .475 & .471 \\
\hline & OCB3 & $.644^{\prime \prime}$ & $.524^{\circ}$ & $.703^{\prime \prime}$ & .652 & $.607^{\prime \prime}$ & $.486^{\circ}$ & $.501 "$ \\
\hline & OCB4 & $.547^{\prime \prime}$ & $.400^{\circ}$ & $.689^{\circ}$ & $.617^{\prime \prime}$ & .568 & $.474^{\circ}$ & $.471^{\circ}$ \\
\hline & OCB5 & .646 & $.527^{\circ}$ & .704 & $.653^{\prime \prime}$ & .606 & $.485^{\circ}$ & $.500^{\circ}$ \\
\hline & OCB6 & .604 & .492 & .665 & .669 & .579 & .459 & .539 \\
\hline & OCB 7 & $.424^{\circ}$ & $.415^{\circ}$ & $.446^{\circ}$ & $.419^{\prime \prime}$ & $.550^{\circ}$ & .438 & $.473^{\circ}$ \\
\hline & OCB8 & $.640^{\circ}$ & .518 & $.703^{\prime \prime}$ & $.647^{\circ}$ & .601 & $.479^{\circ}$ & .496 \\
\hline
\end{tabular}

If seen from the table above can be summarized as follows :

1. In the variable Employee Performance Leadership Behavior to have the highest $\mathrm{R}$ value of 0.811 , which explains the correlation between the dimensions of responsibility with Ketepaatan time, where employees are responsible for their work so as to produce timely in the process of the work required by the company. While the value of $r$ low of 0.154 , namely to develop the quantity dimension, in this case the employee has not fully develop its capabilities so that the quantity has not been fully achieved.

2. In the variable Employee Performance Reward System to have the highest $\mathrm{R}$ value of 0.818 , which is the correlation between the dimensions of benefits paid to employees in the form of money or financial such as salaries, bonuses and benefits with ketepaatan time. While the value of $\mathrm{r}$ low of 0.481 , the dimensions of the benefits given to employees in the form not of money as authority, appreciation and appointment of staff 
as representatives of companies with quantity.

3. On Organizational Citizenship Behavior variables to Employee Performance has the highest $\mathrm{R}$ value of 0.704 , which is the correlation between the dimensions comply with the company even though no one is watching with ketepaatan time, so employees although not supervised by their superiors will obey and do the work in a timely manner. While the value of $r$ low of 0.393 , the dimensions willingness of employees to replace another employee tasks where time is concerned are unable to perform tasks with the quantity, where the lack of awareness coworkers who want to help do the work colleague who was unable to attend to increase the quantity of the work.

Discussion

The effect of each variable research related to the theory and a review of previous studies may be explained in the discussion of the research results in detail as follows:

1. Leadership Behavior has effect to OCB (Organizational Citizenship Behavior) (Hypothesis 1), $\mathrm{T}$ statistics amounted to 3.470 greater than the value of the $\mathrm{T}$ table $=$ 1.655 , and P-Values $=0.001$ which is less than $\alpha=0.05$. The value of the coefficient is positive, meaning that the variable that is equal to 0.341 Leadership Behavior positive effect on the variable Organizational Citizenship Behavior. Leadership Behavior variables will affect the variable Organizational Citizenship Behavior 34.1\%. Therefore, the behavior of the leader is very important in the behavior of civic organizations. Where an employee is able to help his co-workers for their role of leader behavior. This is also confirmed by the research of Anggita, Gede \& Dharmanegara (2018) which showed that the Leadership and Organizational Citizenship Behavior (Ocb) significantly affects Work Stress and Employee Performance. Thus the hypothesis H1 in this study which states that "There is the effect of Leadership Behavior on Organizational Citizenship Behavior" accepted.

2. Reward System has effect to OCB (Organizational Citizenship Behavior) (Hypothesis 2), $\mathrm{t}$ statistics amounted to 4.555 greater than $\mathrm{t}$ table $=1.655$, and $\mathrm{P}-\mathrm{Values}=0.000$ less than $\alpha=0.05$. The value of the coefficient is positive, amounting to 0.454 means Reward System variable positive effect on the variable Organizational Citizenship Behavior. Reward System variables will affect the variable Organizational Citizenship Behavior of $45.5 \%$. therefore, reward systems effect on organizational citizenship behavior. Wherein when employees are met allowances, awards received for his hard work, the employee 
will help coworkers on the job voluntarily. This is also confirmed by the research of SIH (2018) which showed that there was a significant effect of the award on the organizational culture and employee performance, and that there is a significant effect of organizational culture on employee performance. Thus the hypothesis $\mathrm{H} 2$ in this study which states that "There is a Reward System effect on Organizational Citizenship Behavior" accepted.

3. Leadership Behavior has effect to Employee Performance (Hypothesis 3), T statistics of 1,982 that is greater than the value of the $\mathrm{T}$ table $=1.655$, and $\mathrm{P}$-Values $=0.048$ which is less than $\alpha=0.05$. The value of the coefficient is positive, meaning that the variable that is equal to 0.185 Leadership Behavior positive effect on the variable Employee Performance. Leadership Behavior variables will affect the variable Employee Performance by $18.5 \%$. Therefore, the behavior of the leader is very important to work productivity. Therefore, a leader must be able to effect and change the attitudes, behavior patterns subordinates so that they work for the sake of the organization. If productivity is good, then the employee's performance increased. This is also confirmed by the research of Sugeng, Mandey and Wenas (2016) the Behavioral Leadership, Commitment, and Communications positive and significant effect on the variable Employee Performance. Thus the hypothesis H3 in this study which states that "There is the effect of the Employee Performance Leadership Behavior" accepted.

4. Reward System has effect to Employee Performance (Hypothesis 4), T statistics amounted to 6.673 greater than the value of the $\mathrm{T}$ table $=1.655$, and P-Values $=0.000$, which is less than $\alpha=0.05$. The value of the coefficient is positive, meaning that the variable that is equal to 0,559 Reward System has a positive effect on the variable Employee Performance. Reward System variables will affect the variable Employee Performance $55.9 \%$. Therefore, it is very important in the reward system to motivate employee performance. Because through reward employees will be more qualified and responsible to a given task. With motivated employees will improve its performance so as to spur employees to improve the quality of work. This is also confirmed by the research of Widyaningsih (2017) that confirms the Effects of Reward and Punishment on Employee Performance. Thus the H4 hypothesis in this study which states that "There is the effect of the Employee Performance Reward System" accepted.

5. Leadership Behavior, Reward Systems and Organizational Citizenship Behavior significantly has effect to employee performance (Hypothesis 5), The (R2) value of 
Leadership Behavior, Reward System, and Organizational Citizenship Behavior is 0.724 with $\mathrm{F}$ statistics for 126.84 and $\mathrm{F}$ table of alpha for 0.05 is 2.67 . The results reveal that (f statistic 126.84> f table 2.67) then H5 is accepted. In other words, that is significant effect between Leadership Behaviour and Reward System on Employee Performance mediated by Organizational Citizenship Behaviour.

\section{CONCLUSION AND SUGGESTION}

\section{Conclusion}

Based on the results of research and discussion in the previous chapters, the following conclusions can be made:

1. Leadership Behavior and significant effect on Organizational Citizenship bahaviour PT Danpac Pharma, with the strongest dimension Relationship Oriented Behavior.

2. Reward System and significant effect on Organizational Citizenship bahaviour PT Danpac Pharma, with the strongest dimension of Financial Reward.

3. Leadership Behavior and significant effect on the Employee Performance PT Danpac Pharma, with the strongest dimension of Task Oriented Behavior.

4. Reward System and significant effect on the Employee Performance PT Danpac Pharma, with the strongest dimension of Financial Reward.

5. Leadership Behavior and Reward System no effect on Employee Performance Mediated by Organizational Citizenship Behavior (OCB).

\section{Suggestion}

Based on the results of research and discussion in the previous chapters, the following conclusions can be made:

1. for Companies

Results of the analysis showed that the correlation between the dimensions to meet the need to optimize the performance of employees significantly the need for information provided delivery of the vision and mission of the company to employees, job responsibility, long-term plan. So companies need to do the following :

a. Head of the company in order to monitor tasks and support employees and maintain good relationships with co-workers in order to avoid problems between employees.

b. Head of the company in order to monitor the business environment and encourage innovative thinking competitor employees to the company's progress.

c. Head of the company in order to provide allowances and promotions and awards for 
employees who excel.

d. Head of the company in order to provide its employees in terms of helping his coworkers who are having difficulty in the present situation both regarding their duties within the organization.

e. Head of the company in order to check employees can complete the work activity at the beginning of time.

2. For further research

a. The author feels there are still many weaknesses in this study. For those interested in further research on the same topic, suggested exploring the effect of independent variables on employee performance, and involve other variables such as: organizational commitment, organizational culture, job satisfaction to predict the performance of employees.

b. For further research to develop a research model by developing the sample population are more varied so that it can be a useful input for the company.

\section{REFERENCE}

Anggita, WN, Gede, WI and Dharmanegara. (2018). Effect of Leadership and Organizational Citizenship Behavior (Ocb) on Work Stress and Employee Performance in Denpasar Tourism Office. Journal of Economics and Business, Volume 5, Number 2, 2018, pp. 138144.

Arianto, AND (2013). Effect of Discipline, Work Environment and Work Culture Lecturer on Performance. Economy Journal, Volume 9, Number 2, October 2013, Page: 191-200.

Budihardjo, Andrea. (2016). A Guide Book Effective Knowledge Management Innovating Achieving Success. Jakarta: Prasetya Mulya.

Karami, A., Hossein, RD \& Saeed, R. (2013). Analyzing the Effectiveness of Employee Reward Management System on Performance through the mediating Role of Employee Motivation Case Study: Isfahan Reginal Electric Company. International Journal of Academic Research in Business and Social Sciences, 3 (9), 327-338.

Moorhead and Griffin. (2013). Organizational behavior. Jakarta: Four Salemba.

Sihombing, S, et al. (2018). The e ff ect of servant leadership on rewards, organizational culture and its implicationfor employee's performance. International Journal of Lawand Management, Vol.60 No.2,2018 pp. 505-516.

Sugeng, Ayu, Mandey, Silvia and Wenas, Rudy. (2016). Effect of Leadership Behavior, Commitment and Communication to Employee Performance PT. Target Jaya Manado. EMBA Journal, Vol.4 4 September 2016, p. 311-320.

Sugiyono. (2016). Educational Research Methods Quantitative Approach, Qualitative and R \& D. Bandung: Alfabeta.

Robbins, Stephen P. \& Judge, Timothy A. (2017). Organizational Behavior. Volume 13. Issue 1. Jakarta: Four Salemba.

Tambe, Sukhada and Shanker, Meera. 2014. A Study Of Organizational Citizenship Behavior (OCB) And Its Dimensions: A Literature Review. 70 International Research Journal of Business and Management - IRJBM. Vol 1, Page 67-73 
Wahab, Abdul Aziz. (2011). Anatomy of Organization and Leadership Education, CV. Bandung: Alfabeta.

Widyaningsih. (2017). Reward and Punishment effect on Employee Performance PT. Kereta Api Indonesia (KAI) Limited Daop V Purwokerto Kutoarjo Station. Thesis. Purworejo Muhammadiyah University.

Yukl, Gary. (2017). Leadership in Organizations, Seventh Edition, Jakarta: PT. Index. 